\title{
SOURCES OF COMPETITIVE ADVANTAGE IN SHAPING THE COMPETITIVE POSITION OF POLISH EXPORTERS ON FOREIGN MARKETS
}

\author{
Piotr Markiewicz*, Agnieszka Żbikowska \\ Faculty of Management, Cracow University of Economics, Cracow, Poland
}

\begin{abstract}
The article presents the role and place of a competitive strategy in the strategic management of a company. It also describes the basic types of competitive strategies as well as sources of gaining a competitive advantage, including both tangible and intangible resources. In an empirical part, the authors discussed the results of the studies conducted among Polish entrepreneurs exporting products to international markets. Researches related to the conditions of shaping a competitive advantage by Polish exporters on foreign markets. The high quality of products, customisation to the needs and expectations of customers, a quick and flexible response to market signals as well as - to a limited extent - the image of the country of origin proved to be the main features of achieving competitive advantage by Polish exporters.
\end{abstract}

Keywords: competitive strategy, competitive advantage, Polish exporters

\section{JEL Classification: F23}

\section{INTRODUCTION}

Without a doubt, exportation is the dominant form of Polish companies' entry into foreign markets. This thesis is confirmed by the results of numerous studies (Witek-Hajduk, 2010; Strzyżewska, 2011). At the same time, the results of previously conducted studies do not always fully identify strategies enabling Polish exporters to compete with rivals outside the Polish borders. The cognitive goal of the article was to identify the key determinants of success and their role in

\footnotetext{
* Correspondence to: P. Markiewicz, Cracow University of Economics, Department of Accountancy, Rakowicka street 27, 31-510 Cracow, Poland; e-mail: piotr.markiewicz@uek.krakow.pl
}

Review paper doi: $10.5937 /$ ekonhor1301061M 
The basic methods deployed during the study involved a postal and online survey and a questionnaire-based telephone interview. The study involved two groups of companies: leading Polish exporters (companies featured in the ranking of the 100 largest exporters compiled by the journal "Polityka" and published in 2006-2010), and about 20000 companies from the Poland-Export database. The significance of the exporters featured on "Polityka's" list for Poland's foreign trade can hardly be overestimated. On average, the 100 companies ranked as the largest exporters have sent abroad goods worth about one-third of the whole of Polish exports. In 2010, the companies featured in "Polityka's" ranking accounted for $36.1 \%$ of Poland's exports (the value of the 100 largest exporters' exports totalled 173,430.2 million PLN compared to the total exports of 481,058.2 million PLN). Overall, 141 completed questionnaires were admitted for a further analysis.

\section{THE PLACE OF THE COMPETITION STRATEGY WITHIN THE STRATEGIC MANAGEMENT OF A COMPANY}

A strategy is a complex concept whose meaning continually evolves. From the etymological perspective, the concept of a "strategy" comes from a Greek word "strategos", which means the directing of troops from the standpoint of a supreme commander. The usage of this concept dates back at least 400 years $\mathrm{BC}$; however, in the literature, it appears only at the end of the 18th century (Jeżak, 1990, 9). From that time all the way to about the 1960 's, the category was particularly related to the military terminology, where the strategy was understood as a part of the warfare including the preparation and waging of a war as a whole (Pszczołowski, 1978, 232).

The concept of a strategy was introduced into management by A. Chandler, who described the strategy as "setting long-term goals and objectives, courses of action and allocation of resources necessary to achieve these goals (Chandler, 1962, 13). The strategy used to be treated as an instrument enabling the ensuring of the balanced operations of an organisation in an increasingly dynamic and competitive environment.
"The field of strategy has evolved substantially in the past twenty-five years. Firms have learned to analyze their competitive environment, define their position, develop competitive and corporate advantages, and understand better how to sustain advantage in the face of competitive challenges and threats. Different approaches - including industrial organization theory, the resource-based view, dynamic capabilities and game theory - have helped academicians and practitioners under- stand the dynamics of competition and develop recommendations about how firms should define their competitive and corporate strategies" (Casadesus-Masanell \& Ricart, 2010, 195).

Strategic management is both a field of knowledge and a practical activity. It includes general principles and methods as well as detailed techniques. The complexity of the potential of a company implies that strategic management includes the application of various diverse approaches and research methods (Stabryła, 2000, 21). The genesis of strategic management is associated with works of such authors as: A. D. Chandler, H. I. Ansoff, P. Drucker. ${ }^{1}$

The concepts of strategic management emerged as economic orientations, research approaches and a strategic behaviour. One of the proposals to clarify the concepts of strategic management is the classification of strategic thinking schools, proposed by K. Obłój (Obłój, 2007, 54-57). The classification is based on three criteria: a decision-making freedom, the formalisation of the strategy and the focus on the strategy. Assuming these criteria, the author lists the following schools of strategy, namely:

- planning,

- evolutionary,

- positional,

- a resource-based view,

- simple rules, and

- feasible options.

Each of the above-mentioned schools has its own approach to the definition of the strategy and the developed methodology of its formulation. A vast number of the definitions of the strategy identified in reference books are the proof of their substantial diversity, arising from various approaches or methodological approaches presented by their authors. 
We can identify attempts to classify this set. One of the most interesting is the typology setting together known in the literature concepts of the strategy in the following four main groups (Obłój, 2007, 18-21):

- a strategy involves the development and execution of an action plan;

- a strategy is reduced to the position of an organisation against the environment;

- a strategy is a relatively constant pattern of the action of an organisation, a set of certain fixed rules, methods, and reactions supported by organisational culture;

- a strategy is the process of the self-identification of an organisation, discovering and shaping its identity, its own "self".

Given the strategy characterizing methods presented above, and particularly the elements exposing the role of the resources of an organisation, two definitions emphasising the feature addressed in this article were presented:

- K. Ohmae believes, that the strategy is an approach aiming at the most favourable distinguishing a company against its competitors (Stabryła, 2000, 12),

- R. W. Griffin - a well-thought-out strategy is the one focused on the four key factors: the coverage of a market, the method of distribution, distinctive competences and a synergy (Griffin, 2004).

In the first case, distinguishing a company is possible through possessing unique resources difficult to imitate. However, in the second definition, we are interested in distinctive competences and a synergy arising from the utilization of these resources.

The above-discussed studies on a strategy as the key concept of strategic management enable us to conclude that the definitions of a strategy reflects a specific substantial consideration of the authors and all these definitions can be regarded as the considerations expressing the essence of the issue. The goal for which the concept is being defined shall be a factor determining which of them is practically applied.

Another important substantial feature from the perspective of an analysed issue is the strategy typology. The most general strategy typology is a division based on a structural criterion. The classification based on that criterion includes (Krupski, Niemczyk \& Stańczyk-Hugiet, 45):

- strategies of a company (corporation),

- strategies of the fields of operations (business domains), and

- functional strategies.

These kinds (types) of the strategy are further divided through the application of the generic division criteria (a product, a market, a specific production potential). Figure 1 below presents an example of the division of strategies at previously distinguished levels.

The levels of the strategy complemented with a fourth level - the network level are increasingly frequently mentioned in the literature. This approach is presented by B. de Wit and R. Meyer $(2007,25)$, who mention:

- the network level (alliances, partnerships),

- the corporation level (domains in which a corporation wants to operate),

- the domain level (the competition strategy), and

- the functional level (functional divisions).

At the domain level (the fields of operation), the basic issue to be resolved is the question whether the activities of a company should be targeted by the market (the environment) or by the possessed resources.

\section{SOURCES OF THE COMPETITIVE ADVANCE}

Individual companies differ in distinct sets of goals as well as the approaches and means of achieving these goals. The strategy is an instrument through which companies strive to achieve long-term goals. However, both the environment and the companies themselves are dynamic systems, subject to constant changes. Therefore, we face the constant search for methods of adjusting the existing as well as potential strengths and weaknesses, opportunities and threats present in the environment. In order for a company to improve its competitiveness, the company shall constantly look 


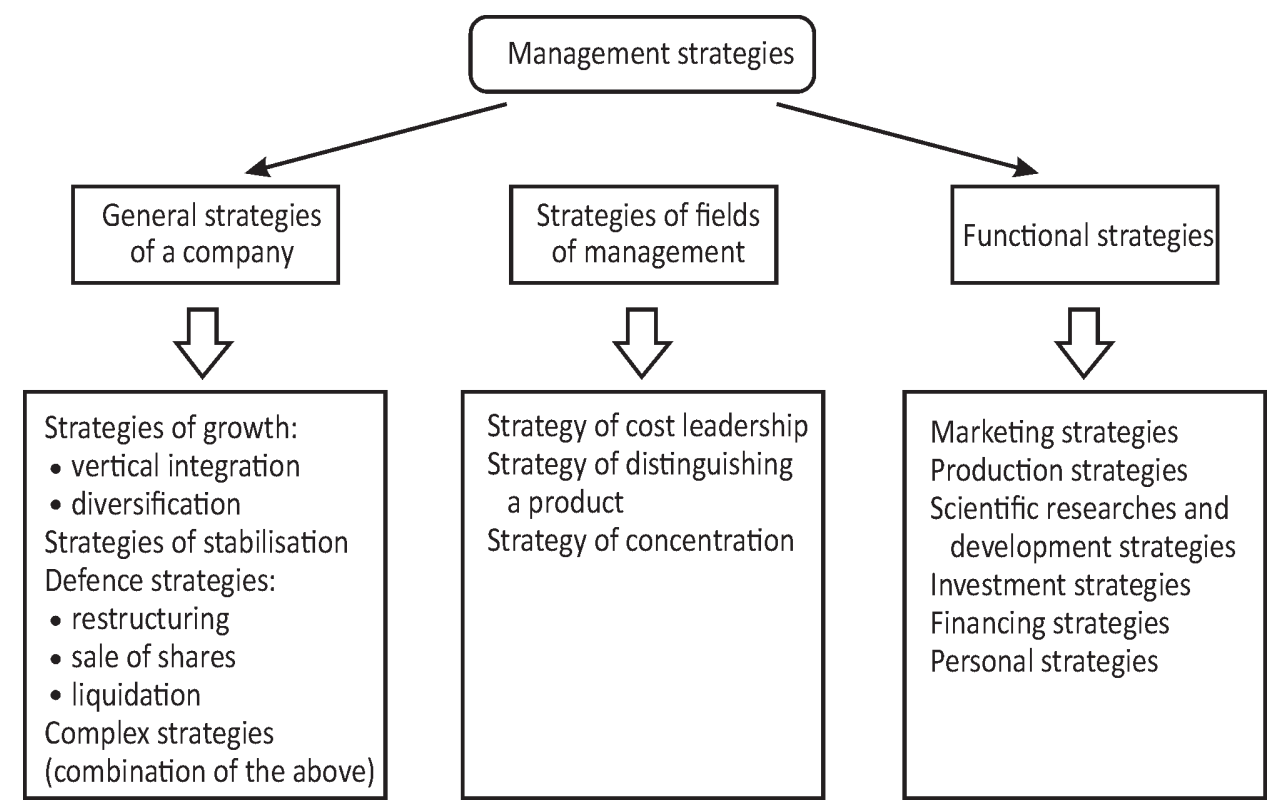

Figure 1 Classification of management strategies

Source: The authors' study based on Stabryła, 2000, 58

for sources of the competitive advantage, within the selected domains of its activities.

A company's competitiveness can be seen as its ability to (Adamkiewicz-Drwiłło, 2002, 128; 246-248):

- boost its productivity (thanks to increasing the efficiency of outlays or achieving the greatest possible outcomes of its resources);

- create development trends (through its increased production, particularly of modern, high-quality products relying on the latest technology);

- effectively develop sales markets (under conditions in which competitors offer more modern, better or cheaper products).

A company's ability to use its potential in these three areas is the way for it to gain a competitive advantage, which is also a determinant of its success in the market. The increasing globalization of the economy, however, means that gaining dominance over the competition is getting tougher. The competition model proposed by M. E. Porter (2008) in the concept of "five forces" must be viewed from the international point of view. G. S. Yip (1996, 53-54) notes that competition between companies in the global space stems from the following:

- a growing threat posed by new market entrants, resulting from the reduction in entry and exit barriers;

- stiffening competition between companies operating in the market;

- an increased risk of substitution - the area from which substitutes can come is expanding;

- the globalization of customers and the strengthening of their bargaining power relative to sectoral competitors;

- the globalization of competitors, which undermines buyers' bargaining power. ${ }^{2}$

J. B. Barney proposes to assess the operations of a company based on the four categories of its outcomes (Barney, 2007, 31-46):

- survival as a measure of performance,

- factors used in accounting (a financial analysis), 
- multi-criteria analysis from the perspective of stakeholders, and

- the value of a company.

The latter can be calculated in many ways. One of them is an analysis of changes in the book value, which, however, is imperfect, due to the fact that it only reflects some part of the resources possessed by a company, i.e. resources which can be estimated (the so-called visible resources). More and more frequently, the market value measure is applied because it has an advantage over the book value, namely it covers certain groups of intangible resources (assets) at the disposal of a company.

The modern economy, described as "the new economy", is characterised by a weakening role of tangible resources in favour of intangible resources. The competitiveness of a company is based on its capacity to rapidly change and create the added value. Therefore, companies should be characterised by the following features (Borowiecki \& Romanowska, 2001, 27):

- flexibility - including the capacity for rapid investments, at low fixed costs,

- cooperativeness - including the capacity for cooperation with suppliers and customers, the capacity for concluding strategic alliances with competitors,

- intelligence - including extended intellectual capital, investments in employees and development.

Therefore, it is important to look at these resources from the perspective of their usefulness for creation of competitive advantage and the capacity to generate efficient competitive measures that affect the development and the success of a company in the long perspective.

The sources of competitive advantage, its types and the way how companies create own advantages are the basic questions that will be answered in order to sustain efficient competition. M. Porter identifies competitive advantage with the nature of the competition strategy (Porter, 2008). Competitive advantage can be understood more broadly, as a capacity to implement a strategy that can be implemented neither by the current competitors nor the potential ones. If, at the same time, none of the competitors can obtain such benefits as are generated by this strategy, one can speak of a permanent or relatively permanent competitive advantage (Barney, 1991, 102-103). The essence of competitive advantage is that a company can do something better than or differently from its competitors, and therefore achieve better results. Competitive advantage is relative and depends on the situation. It also depends on whether rivals are able to proceed in the same way. A company's success is associated with the possession of competitive advantage and therefore is interested in creating a sustainable competitive advantage as well as in the maximisation of the results obtained due to the nature of competitive advantage. The basic dimensions of competitive advantage (its type, size and durability) depend on numerous external and internal features.

The type of competitive advantage is a diversity of behaviours and operations of a company in relation to its competitors. The character of the competitive advantage can be defined through a comparison of the operations and behaviours of various companies. Particular competitive advantages are externally determined. They do not arise from what a company can do, but how it presents itself in relation to others.

The size of the competitive advantage is defined as a difference of parameters describing behaviour and operations of a company and its competitors. Therefore it does not depend only on efforts of a company, but also on what its competitors do.

The sustainability of competitive advantage shall be understood as a period of time in which a company possesses such an advantage over its competitors. Once gained, competitive advantage does not guarantee better results in a longer perspective. Competitive advantage may be reduced through operations performed by competitors who, thanks to the acquisition of proper resources, obtain similar skills enabling them to operate in a similar way.

The competitive advantage dimensions discussed above are conditioned by external factors. Formulating a competition strategy, a company seeks attractive areas of activities. Within these areas, it undertakes operations aimed at reaching a better position than its competitors. This approach, however, does not explain 
a very important issue, namely what the sources of competitive advantage are, why some companies are able to identify attractive areas of operations more effectively, why they are able to defend their oncegained competitive advantage, while others are quickly faced with the loss of such an advantage. Answers to these questions shall be found through the analysis of differences in the status of the basic resources and factors deciding on the choices made by them.

What a company does, and how it competes, depends on its objective capacities, conditioned by the possessed resources, and on decisions related to the usage of these resources. Competitive advantage, whose basic dimensions are defined by a widely understood environment, is generated inside a company. The origins of the competitive advantage are strictly related to a company's resources and their usage.

History also shows that over time, sectors and industries are constantly being developed and expanded. The conditions and limitations of these sectors can shape individual actors (companies) (Chan Kim, W., \& Mauborgne R., 2005, 25-30).

The problem related to the characteristics of the resources deciding on their importance for competitive advantage was developed by J. Barney (Barney, 1991, 91-120). Considering the model of a company from the perspective of its resources, the author introduces two basic assumptions. First, companies within the frameworks of a particular field of operation or a strategic group may differ in terms of the resources in their possession. Second, these differences can last for a long time due to the restricted mobility and availability of such resources. These resources are the basis for a resource-based view. Companies with competitive advantage in a form of better resources, thanks to which they implement efficient strategies, will be able to sustain this advantage as long as competitors do not operate in the same way. Competitors will be able to operate in the same way depending on the availability of these resources or the capacity to have them substituted.

In order to constitute the basis for an efficient strategy and have an influence on the creation of a sustainable competitive advantage, resources must have the following features, namely they must be (Barney, 1991, 112):

- strategically valuable - based on them, the company is able to exploit advantages or resist threats;

- characterised by the rarity of possession by the current and potential competitors;

- difficult to imitate, or copy;

- irreplaceable by other types of resources.

Relations between the character of resources possessed by a company and the sustainability of a competitive advantage possible to generate based on these resources are accounted for in Figure 2 below.

A particular difficulty to imitate or copy resources distinguished in the diagram can be caused by various factors. Historical dependencies are primarily related to the moment of obtaining particular resources, which can be inaccessible for others (e.g. a favourable location).

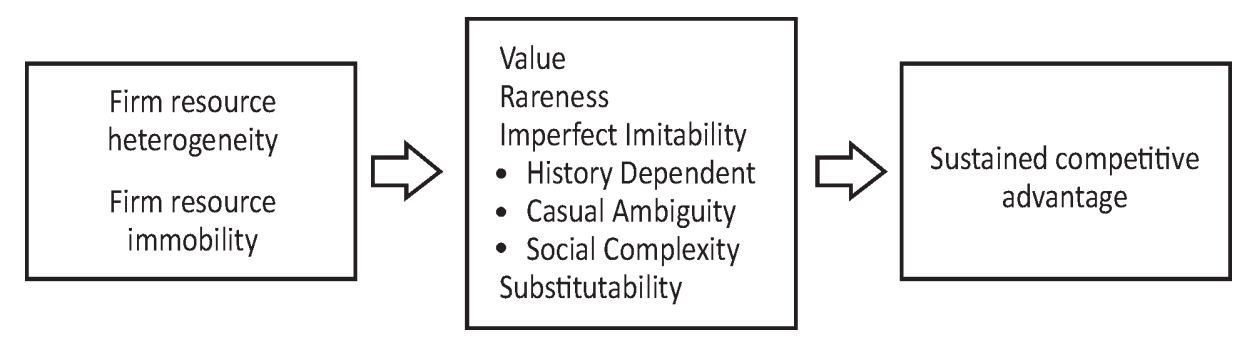

Figure 2 Relations between the character of resources and the competitive advantage of a company 
The ambiguity of causal relations occurs when competitors have difficulties in identifying the reasons why a particular company possesses a competitive advantage, or what resources constitute the basis for this advantage.

The social complexity refers to the so-called intangible resources, such as specific relationships, the organisational culture of a company, the specific system of relations with the environment. Resources of this kind are rather difficult to imitate.

A limited capacity to substitute strategically valuable resources means that, in relations to a particular, there is no substitute that could allow for the creation of similar advantage, or generate the same strategy. Substitutive resources can have a completely different form. Their substitution does not depend on the similarities between them, but rather on the capacity to obtain similar results through them.

According to M. A. Peteraf, the basic condition needed for obtaining a competitive advantage is the diversity of such resources through which it is possible to obtain this advantage (Peteraf, 1993, 179-188). Diversity is understood as both the existence of various forms of resources and the diversity of the features of the possessed resources. Maintaining the favourable competitive position, obtained through the possessed resources, in a long perspective is possible only if other companies are unable to acquire similar resources, and therefore similar skills. A condition for this is the existence of the limitations of competition as well as the limited mobility of resources. Limitations of competition come down to the fact that other companies cannot obtain resources ensuring a company its competitive advantage or the costs of acquisition of such resources are very high. These limitations can also indicate a situation when resources important for the future competition are restricted or their strategic value is difficult to identify when companies compete to obtain these resources. If projections related to its strategic importance are confirmed in the future, a company can take a privileged position.

The competitive potential of a company changes depending on external conditions and the internal capacity of the company. At a particular moment of time, each company has a certain competitive potential which can be understood, as has already been mentioned, as a system of tangible and intangible resources. To compete efficiently and therefore develop successful strategy, it is important to carefully identify the components of this potential.

In the modern economy, we can observe a growing role of intangible assets. Obtaining and maintaining a competitive advantage is related to the ownership of resources both unique and difficult to imitate. An access to technology, equipment, and financial resources no longer provides such a source of competitive advantage.

If managers could find a way to estimate the value of their intangible assets, they could measure and manage their company's competitive position much more easily and accurately (Kaplan \& Norton, 2004).

\section{TYPES OF COMPETITIVE STRATEGIES}

A company's competitive advantage arises from the unique benefits which the company provides its customers with (Keegan \& Schlegelmilch, 2001, 343). On the other hand, the given kind of advantage is linked with a relation between buyers' benefits and the costs which the company must incur to gain these benefits (Garbarski, 2011, 56). In this context, one should note (Graph 1):

- cost advantage or

- non-cost related advantage.

From the customer's point of view, advantages can manifest themselves through prices lower than rivals' product prices or higher product attractiveness (in a broad marketing approach). It may be very difficult to get a head start over competitors operating in the market and having diverse resources and experience. For this reason, many companies opt for a middleof-the-road approach consisting of a compromise between the product price and its utility value as perceived by the consumer, without getting a clear competitive advantage.

It should be noted that competitive advantage can be seen from either/ both consumers' or/and competitors' points of view. Both of these approaches are closely 


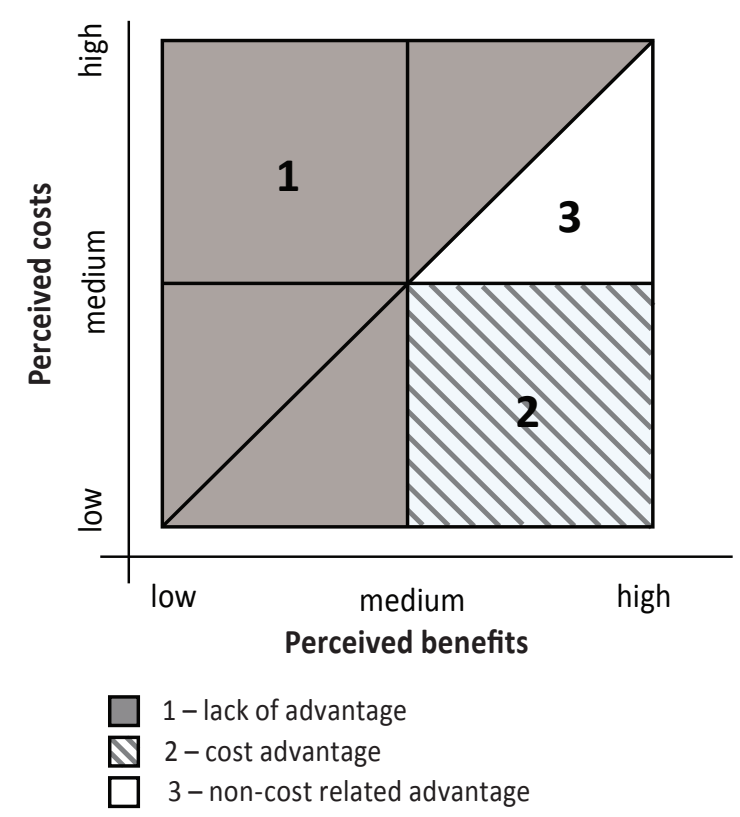

Graph 1 Map of buyer's benefits

Source: Best, 2009, 206

related to each other. Addressing a company's strategy to market competitors involves comparing the costs incurred by competitors, their production technology, market share, marketing tools used, etc. with the same in the company. However, this comparison cannot occur in isolation from consumers' needs and the benefits they expect.

Thus, customer service strategies focus on:

- the offer's value perceived by consumers (benefits), and

- perceived costs (product price).

One's taking his or her competitors into consideration makes it easier for them to gain a competitive advantage relying on the use of one of the following two competitive strategies (Strategor, 1995, 78):

- the cost strategy or

- the differentiation strategy.

Under the cost strategy, the main objective is reduction in overall costs, which, on the one hand, will allow the company to offer its product at a low price and, on the other, to generate higher profits. Reduction in total costs may results from a lower variable unit cost (due to the economies of scale and experience), reduction in spending on marketing activities (this will be facilitated by standardization) and reduction in operating costs. The cost strategy bears fruit when the main criterion for consumers' purchasing decisions is the product's price and when all buyers have similar expectations of the product and do not feel a need for additional variations of the product.

On the other hand, the differentiation strategy is associated with a product's specificity. The company aims to create a unique offering in the market, which buyers will be willing to pay a higher price for. The higher attractiveness of the product can result from its various features, for example: its above-average quality or durability, the latest technology, the brand and the supporting positive image, a registered utility model, the customer service support at the point of sale or after-sales services. A key factor in the success of this strategy is customer loyalty. Loyal customers are less price sensitive, so a low price level is not the main goal of the differentiation strategy. Product differentiation should refer to a possibly vast number of its features. The more difficult it is for competitors to imitate the actions linked with the product policy, the longer the company can retain its competitive advantage.

M. E. Porter (2008) indicates the additional third customer-service strategy - the concentration strategy. It involves concentration on serving a niche market, a narrow consumer segment and an offer of a highly specialized product. This leads to gaining a dominant position in the segment, similar to the monopoly position, often as a result of the lack of competitors who have found it unprofitable to operate in a small market. It appears however that this strategy is a variation of the differentiation strategy as it is based on a unique offer.

In discussing strategies for engaging with the competitors, one can point out yet another aspect of the problem. A company acting in a given market, against an array of competitors, must decide on its place among its rivals. In the broadest terms, one can point out four groups of competitive strategies (Wrzosek, 2004, 59-62):

- competition avoidance strategies,

- defensive strategies,

- active (creative) strategies, and

- adaptive strategies (passive). 
Competition avoidance is a peculiar type of conduct in relation to competitors. In fact, it implies withdrawing from competing against rivals but can also manifest itself in establishing cooperation with rivals (e.g. a joint venture established in foreign markets). A company may also seek to eliminate competitors either through an acquisition or an efficient use of its resources, conducive to the gaining a very large market share. Companies may also choose to "ignore" competitors with a poor market position, when these do not pose a real threat.

In their defensive strategies, companies concentrate on maintaining their current market position. Typically, this approach is used by companies having a large market share or operating in a distributed but highly active market. The development of a company is to occur at a pace commensurate with the development of the supported market.

Active strategies are associated with undertaking novel actions, pre-empting competitors' moves. Companies employ this strategy when the market is growing slowly, and they expect to increase sales faster. Then the only way is to take over competitors' customers.

Passive strategies, in turn, consisting in adapting their activities to competitors' changing market behaviour are characteristic of companies not having the ability to create innovation. Such companies, taking on the role of market followers (imitators), follow their competitors.

\section{COMPETITIVE ADVANTAGE FACTORS OF POLISH EXPORTERS - RESEARCH RESULTS}

The surveyed exporters indicated what elements were important to build a competitive advantage abroad, and what activities accounted for the company's competitive position in a foreign market (Table 1).

Table 1 Factors playing a significant role in building a competitive advantage in foreign markets and providing a source of actual competitive advantage ( $\mathrm{N}=141)$

\begin{tabular}{lcc}
\hline Item & $\begin{array}{c}\text { Significant } \\
\text { factor }\end{array}$ & $\begin{array}{c}\text { Factor underlying } \\
\text { company's superiority }\end{array}$ \\
\hline Favourable prices and terms of payment & $65.2 \%$ & $50.3 \%$ \\
Thorough knowledge of buyer needs and expectations & $65.2 \%$ & $42.6 \%$ \\
High quality of products & $58.2 \%$ & $63.1 \%$ \\
Highly qualified and experienced staff & $58.2 \%$ & $48.2 \%$ \\
Effective distribution system & $56.0 \%$ & $29.8 \%$ \\
Products tailored to customer needs and expectations & $55.3 \%$ & $59.8 \%$ \\
Partner relations with agents in foreign markets & $51.8 \%$ & $39.0 \%$ \\
Modern technology & $50.4 \%$ & $31.2 \%$ \\
Responsiveness to market changes & $50.4 \%$ & $56.0 \%$ \\
Relatively low costs of operations & $48.9 \%$ & $33.3 \%$ \\
Well-known brand name & $44.0 \%$ & $31.9 \%$ \\
Regular and effective promotion activities & $42.6 \%$ & $9.9 \%$ \\
Unique product/service offering & $40.4 \%$ & $39.7 \%$ \\
The company's engagement in corporate social responsibility - & $15.6 \%$ & $3.5 \%$ \\
social campaigns in foreign markets & & \\
Links between the company's and mother company's offering & $14.2 \%$ & $7.8 \%$ \\
\hline
\end{tabular}

Source: The authors' research 
The analysis of the results allows us to conclude that, in exporters' opinion, the attainment of a strong competitive position requires one's having a wide range of advantages over the competition. On average, the respondents acknowledged that the source of competitive advantage should include the simultaneous ownership of as many as seven out of the fifteen proposed factors. A competitive strategy typically involves selecting a small number of success factors (one or several) and streamlining them in order to achieve a competitive advantage (Gierszewska \& Romanowska, 1997, 159-160). The company's simultaneous expansion in many spheres of activity seems to be very difficult, which can be also corroborated by the identification of the elements that actually allowed the surveyed companies to shape their desired competitive advantage. The average number of factors which together constituted the basis of an actual competitive advantage and were pointed out by the respondents declined to five, from the original seven factors indicated as being significant.

In assessing the significance of each factor for building their competitive advantage in foreign markets, exporters ranked the price and payment terms benefitting the customer and good knowledge of customers' needs and expectations number one $(67.6 \%$ of the responses for each of the factors). Suitable prices may indicate the priority afforded to the low-cost competitive strategy. A price which is competitive to the consumer does not clearly determine the amount of costs incurred by the company, but operating costs may determine the final price of the product offered to buyers. Sales revenue cannot, in the long run, remain below the cost of product's manufacture and delivery to final users. Nearly half of the exporters $(48.9 \%)$ emphasised the importance of low operating costs in creating a competitive advantage in foreign markets. Over a third of the companies (35.5\%) indicated both competitive prices and company's low operating costs as the key elements in shaping their competitive advantage.

Exporters highlighted the significant role of the differentiation strategy in capturing foreign markets. As already mentioned, the good knowledge of customers' needs and expectations is particularly important. Consumers' needs are a starting point for developing a suitable product and the basis of distinguishing the company's offer from rival offers available in the market. Such differentiation may be made both at the level of the actual product, or an extended or potential product. More than half of the companies surveyed (55.3\%) asserted that the knowledge of buyers' preferences should be reflected by adapting products to their needs and expectations. The total of $58.2 \%$ of the respondents indicated the parameters associated with a high product quality as a source of competitive advantage. Half of the exporters believed that a modern technology, which could significantly influence the final shape of the offer, was an important determinant of building a competitive advantage. A well-known brand which is an added value to customers was recognized as a success factor by $44 \%$ of the surveyed companies. The unique character of the offer was the final element directly linked with competition based on product features - it was mentioned by $40 \%$ of the respondents.

The surveyed exporters also pointed out the possibility of distinguishing themselves from the competition by aptly developing other marketing tools. The companies recognized the development of sales and distribution systems as particularly important. The total of $56 \%$ of the exporters felt that the creation of an effective distribution system contributed significantly to gaining a competitive advantage, and $51.8 \%$ of the respondents indicated that establishing and maintaining a partnership relationship with foreign intermediaries also helped. A large group of exporters $(42.6 \%)$ stated that the intensive use of the tools of marketing communication with customers in foreign markets was the basis of building a position in the market.

Competitors' diversification strategies affect not only the cost of production or the use of marketing tools, but may be linked to other resources and activities of the company. The total of $58.2 \%$ of the exporters recognized skilled and experienced staff to be a possible source of competitive advantage. Half of the companies also pointed out the ability to quickly and flexibly respond to changes in the environment. These reactions manifest themselves in various activities and may for example involve: 
- increasing production in the face of growing demand;

- modifying a product's features under the influence of modern technology;

- introducing improved or new forms of the customer service associated with the development of computer technology and the Internet dissemination;

- changing prices, allowing rebates and discounts at times of a decline in customers' income;

- establishing cooperation with new partners, offering more favourable terms and conditions.

A small group of the exporters $-15.6 \%$ in all - found that a competitive advantage could be gained by emphasising activities demonstrating the company's
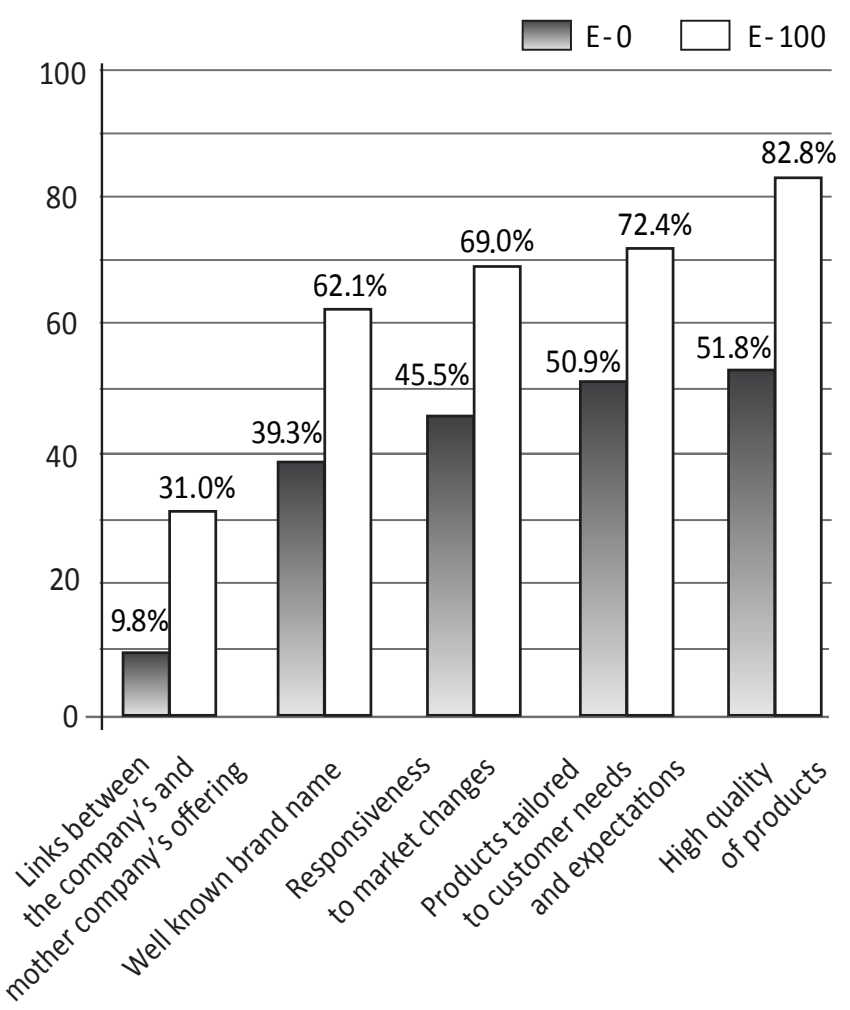

Graph 2 Important factors underlying the achievement of a competitive advantage in foreign markets for companies in the E-100 and E-O groups

Source: The authors' research social responsibility. Companies operating as subsidiaries of foreign entities indicated a possibility of linking their own offer with that of their parent companies' $(14.2 \%$ of the responses). Certainly, the exploitation of a brand already known to foreign consumers and counterparties would be an asset in their case.

The weight afforded by the company to particular factors depended on membership in the group of the biggest exporters. The companies on "Polityka's" list laid an emphasis on the differentiation strategy built on the basis of a product's unique selling features rather than other exporters (Graph 2). Moreover, the largest exporters more often believed that a swift adaptation of the activities to the changing market environment was a condition for gaining a competitive advantage.

The above correlation interestingly dovetails with the assessment of the actual sources of company's own competitive advantage indicated by the surveyed exporters. The elements highlighted especially by the companies on the "Polityka" list as important factors in the market competition were the basis of creating a competitive advantage for most companies. Regardless of their characteristics, the surveyed exporters identified the following sources of competitive advantage in foreign markets:

- high-quality products $-63.1 \%$ of the respondents,

- products geared to customers' needs and expectations $-59.8 \%$ of the respondents,

- an ability to quickly and flexibly respond to the market stimuli $-56.0 \%$ of the respondents.

These results may indicate what plays the key role in shaping the relevant characteristics of the broadly construed product and underlies the Polish exporters' competitive advantage.

The analysis and comparison of the success factors, considered essential and those thanks to which the companies gained a good competitive position, indicate that the companies were aware of a potential for competing at various levels, but chose to focus on creating and developing only so many advantages. In addition to the above three factors, half of the companies perceived attractive prices and payment 
terms offered to consumers to be the sources of their competitive advantage. Simultaneously, the exporters pointed out the areas of activity which, in their opinion, required more involvement. In many cases, the companies recognized a factor to be important, but failed to build their competitive position around it (Table 2).

Particular attention should be paid to the deployment of marketing tools to shape the competitive position. With regard to promotion, the belief that largescale marketing communication can significantly differentiate the company from the market rivals was revealed. On the other hand, probably the high cost of promotional activities made it difficult for companies to apply this marketing tool. Only one in five exporters recognising the great importance of promotion built their position by deploying this success factor.

Table 2 Share of companies enjoying a real competitive advantage

\begin{tabular}{lc}
\hline $\begin{array}{c}\text { Factors of the achievement of a competitive } \\
\text { advantage }\end{array}$ & $\begin{array}{c}\text { Balance of } \\
\text { respondents }\end{array}$ \\
\hline $\begin{array}{l}\text { The company's engagement in corporate social } \\
\text { responsibility }\end{array}$ & $15.8 \%$ \\
Regular and effective promotion activities & $20.0 \%$ \\
Links between the company's and mother com- & $42.9 \%$ \\
pany's offering & $43.6 \%$ \\
Effective distribution system & $53.3 \%$ \\
Relatively low costs of operations & $54.3 \%$ \\
Modern technology & $55.9 \%$ \\
Thorough knowledge of buyer needs and expec- & $63.2 \%$ \\
tations & $67.6 \%$ \\
Well-known brand name & $76.9 \%$ \\
Unique product/service offering & $82.2 \%$ \\
Favourable prices and terms of payment & $82.5 \%$ \\
Highly qualified and experienced staff & $100 \%$ \\
Partner relations with agents in foreign markets & $100 \%$ \\
High quality of products & $100 \%$ \\
\hline Products tailored to customer needs and expec- & \\
tations & \\
Responsiveness to market changes &
\end{tabular}

Source: The authors' research
Distribution was another marketing tool which could be used to build a competitive advantage in the future. More than half of the companies surveyed (56.4\%), acknowledging the importance of an efficient distribution system in competing with rivals, did not consider their own distribution efforts to be a success factor in foreign markets. Almost a quarter of the companies which saw an appropriate pricing policy to be a factor significantly contributing to their competitive position did not have this advantage. Therefore, the adaptation of marketing tools to the different conditions of foreign markets remains a major challenge for Polish exporters. The specificity of foreign markets, the fact that they do not compare with the home market, and exporters' frequently limited opportunity to use the experience gained at home and abroad, coupled with a lack of detailed knowledge of the new environment, all become barriers to development. The product as marketing tools is an exception, though. All companies that asserted the importance of matching goods and services to customers' needs and expectations competed on the basis of this factor. A product that suits customers is the cornerstone of the market presence and a prerequisite for other activities to be successful.

The biggest discrepancies between the readings of the relevant and actual success factors emerged with regard to the activities based on social corporate responsibility. Merely $15.8 \%$ of companies that considered this factor to be a source of a competitive advantage deployed it to build their competitive advantage in foreign markets. A big difference was also ascertained in the statements concerning the possibility of combining exporters' offer with that of the parent company - only $42.9 \%$ of the companies recognising the importance of this factor used it to build their position. Yet, because in both cases only a small percentage of companies pointed out corporate social responsibility and an opportunity to "rely" on the parent company's offer as part of the creation of a competitive advantage, these two are not the factors that should seriously engage the resources of most exporters.

The results presented in Table 2 again show that a high product quality, a product's adaption to customers' needs and expectations and a rapid and 
flexible response to the changing market were the main constituents of the Polish exporters' competitive advantage.

The surveyed companies saw an opportunity to build their competitive advantage based on products of the Polish origin. Half of the exporters claimed that pointing to Poland as the place of a product's manufacture was $(38 \%)$ or could be $(12.4 \%)$ a success factor (Graph 3). Nearly 30\% of the respondents felt that emphasising their products' Polish origin did not help improve their competitive position. It is worth noting that this situation can arise either from an adverse image of Poland as a "specialist" in a given field of production or from apparent lack of importance of the product's origin for its assessment by consumers.

The total of $38 \%$ of the respondents indicated that emphasising the country of origin was already an element of gaining a competitive advantage. Emphasising products' Polish origin could not be disassociated from the geographical area from which consumers come - there is a statistical correlation between these variables. As shown in the Graph 4, products' Polish origin is an advantage for companies

\section{Is the fact that the products were manufactured} in Poland an advantage in foreign markets?

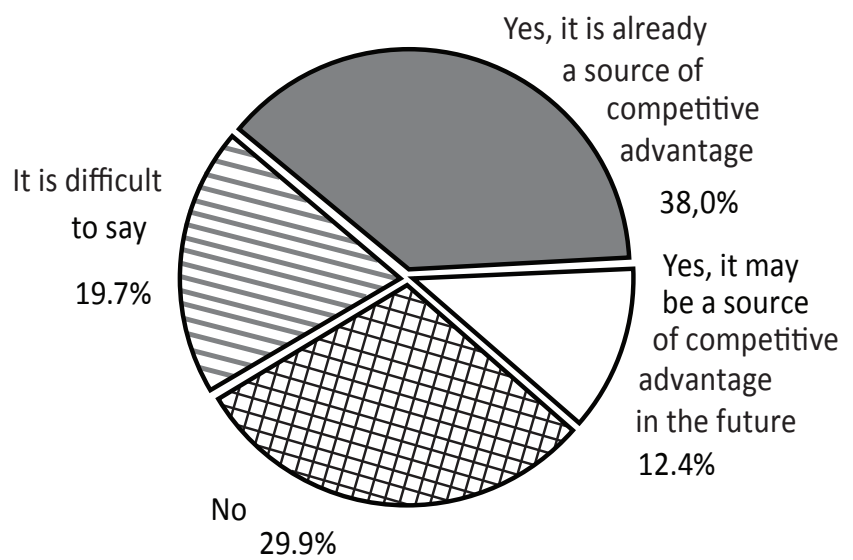

Graph 3 Polish exporters' use of product's origin to build their competitive advantage ( $\mathrm{N}=137)$

Source: The authors' research that supply goods to eastern markets, in particular to the countries of the Commonwealth of Independent States. In this group, $56.7 \%$ of the exporters benefit from Poland's positive image amongst customers. On the other hand, the possibility of highlighting the country of origin in the European Union is limited - merely $31.8 \%$ of the exporters to the EU markets pointed out this factor.

Those companies (27.1\%) for which the EU member states were the main export market could not clearly determine the importance of the country of origin for the products' acceptance by foreign consumers. By contrast, the same difficulty was reported by merely $3.3 \%$ of the exporters to CIS markets. The image of Poland and Polish products may therefore be more diverse among buyers from the EU or the degree to which they take into account the impact of the country

\section{Is the fact that the products were manufactured in Poland an advantage in foreign markets?}

Exporters to CIS

Exporters to EU
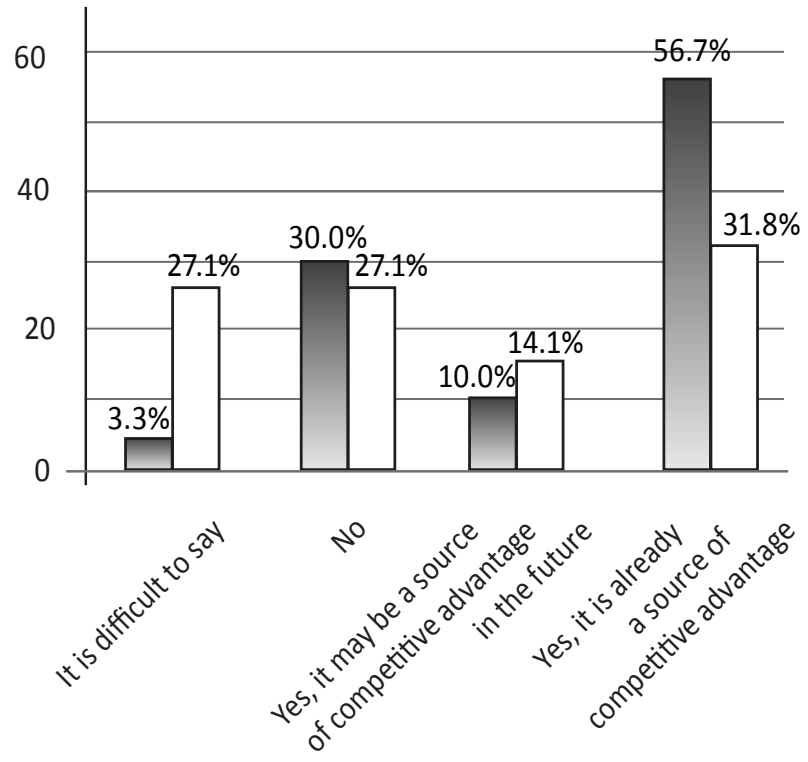

Graph 4 Differentiation of the use of the country of origin in building a competitive advantage between the EU and the CIS $(\mathrm{N}=115)$

Source: The authors' research 
of origin on quality may vary. It therefore appears that those exporters selling in the EU markets who cannot weigh up the impact of the country of origin on the perception of their products should investigate the issue. The results of such analyses would reveal whether the disclosure of the country of a product's origin would be an asset, or conversely, would hurt sales.

\section{CONCLUSION}

Competing in international markets is a necessity in the contemporary economy; however, at the same time, it is an increasingly difficult task. Abundant company resources and the rapidly changing business environment make enterprises actively seek new sources of competitive advantage which ensure developing effective corporate management and competitive strategies.

The main role in gaining a competitive advantage by Polish exporters was played by the development of the suitable features of the broadly understood product, while favourable prices and payment terms occupied less prominent places in the ranking of the factors used to build a market position (H1). The weight afforded by the company to particular factors depended on its membership in the group of the biggest exporters (H2). The companies on "Polityka' s" list laid an emphasis on the product quality and the differentiation strategy built on the basis of the product's unique selling features more than other exporters. Products' Polish origin was of limited importance as a source of competitive advantage (38\% of the respondents) (H3), although more than half of the exporters to CIS markets found that their products' Polish origin was a competitive advantage.

The main conclusion for exporters is that a high competitive position is easier to achieve by means of non-cost competitive strategies and a focus on the broader quality of the offer. Companies should focus on customers' needs and expectations. Exporters should also quickly and flexibly respond to market changes. Exporters to CIS markets ought to consider emphasising their products' Polish origin. It can help to build their competitive advantage abroad.
The research has shown how the surveyed companies perceive the sources of their competitive advantage. An interesting problem for further studies is the issue of the sustainability of these sources of competitive advantage and how they should be modified depending on varying market conditions. An important issue is also to recognise the consumer's opinions of the products and services in question - to what extent they are guided by a low price and to what extent by the quality of a product (service) and the reputation of a company.

\section{ENDNOTES}

1. A. D. Chandler (1962) studied relations between strategies and a structure and formulated, inter alia, a rule, that a starting point for operations of a company is a strategy to which an organisational structure is subordinated. He also supported a decentralisation of management functions, despite the fact, that he ascribed a paramount importance to the planning and coordination functions of management, due to adjustment of operations of a company to spontaneously and autonomously evolving environment. H. I. Ansoff (1968) was a precursor of analytic and planning approach within the strategic management. He presented extended methodology for long-term planning, as well as developed a model concept of a company's strategy and formulated several recommendations for diagnostic researches. P. Drucker (1964) formulated rules for an analysis of products based on concept of categorisation, which could be understood as an element of the strategic analysis. He was also engaged in an economic diagnosis, formulated rules for a cost control.

2. These conditions relate as much to the company's activities in foreign markets as to the same in domestic markets, since globalisation affects all countries' economies.

\section{REFERENCES}

Adamkiewicz-Drwiłło, H. G. (2002). Uwarunkowania konkurencyjności przedsiębiorstwa. Warszawa: PWN.

Ansoff, H. I (1968). Corporate Strategy. Harmondsworth: Penguin.

Barney, J. B. (1991). Firm resources and sustained competitive advantage. Journal of Management, 17(1), 99-120.

Barney, J. B. (2007). Gaining and Sustaining Competitive Advantage. Upper Saddle River: Prentice Hall. 
Best, R. J. (2009). Market-Based management: Strategies for Growing Customer Value and Profitability. London: Pearson, Prentice Hall.

Borowiecki, R., \& Romanowska, M. (Eds.). (2001). System informacji strategicznej: Wywiad gospodarczy a konkurencyjność przedsiębiorstwa. Warszawa: Difin.

Casadesus-Masanell, R., \& Ricart, J. E. (2010). From Strategy to Business Models and onto Tactics. Long Range Planning, 43(2/3), 195-215.

Chan Kim, W., \& Mauborgne R. (2005). Blue Ocean Strategy: How to Create Uncontested Market Space and Make Competition Irrelevant. Boston: Harvard Business Press.

Chandler, A. D. (1962). Strategy and Structure. Cambridge: MIT Press.

De Wit, B., \& Meyer, R. (2007). Synteza strategii. Warszawa: PWE.

Drucker, P. F. (1964). Managing for Results. London: Heinemann.

Garbarski, L. (Ed.) (2011). Marketing: Koncepcja skutecznych działań. Warszawa: PWE.

Gierszewska, G., \& Romanowska, M. (1997). Analiza strategiczna przedsiębiorstwa. Warszawa: PWE.

Griffin, R. W. (2004). Podstawy zarzadzania organizacjami. Warszawa: PWN.

Jeżak, J. (1990). Strategiczne zarzadzanie przedsiębiorstwem: Studium koncepcji $i$ doświadczeń amerykańskich $i$ zachodnioeuropejskich. Łódź: Uniwersytet Łódzki.

Kaplan, R. S., \& Norton, D. P. (2004). Strategy Maps: Converting Intangible Assets into Tangible Outcomes. Boston: Harvard Business Press.

Keegan, W. J., \& Schlegelmilch, B. B. (2001). Global Marketing Management: A European Perspective. Harlow: Pearson Education Ltd.
Krupski, R., Niemczyk, J., \& Stańczyk-Hugiet, E. (2009). Koncepcje strategii organizacji. Warszawa: PWE.

Obłój, K. (2007). Strategia organizacji. Warszawa: PWE.

Peteraf, M. A. (1993). The Cornerstones of Competitive Advantage: A Resource-Based View. Strategic Management Journal, 14(3), 179-191.

Porter, M. E. (2008). Competitive Strategy: Techniques for Analyzing Industries and Competitors. New York: Free Press.

Pszczołowski, T. (1978). Mała encyklopedia prakseologii i teorii organizacji. Wrocław: Ossolineum.

Rocznik statystyczny handlu zagranicznego 2011 (2011). Warszawa: Główny Urząd Statystyczny.

Stabryła, A. (2000). Zarzadzanie strategiczne w teorii i praktyce firmy. Warszawa-Kraków: PWN.

Strategor (1995). Zarządzanie firma. Strategie, struktury, decyzje, tożsamość. Warszawa: PWE.

Strzyżewska, M. (2011). Wpływ internacjonalizacji polskich przedsiębiorstw na ich wyniki ekonomiczne. In Adamik, A. (Ed.), Kształtowanie konkurencyjności i przewagi konkurencyjnej małych $i$ średnich przedsiębiorstw (pp. 263-280). Warszawa: Wydawnictwo C. H. Beck.

Witek-Hajduk, M. K., (2010). Strategie internacjonalizacji polskich przedsiębiorstw w warunkach akcesji Polski do Unii Europejskiej. Warszawa: Oficyna Wydawnicza, Szkoła Główna Handlowa w Warszawie,

Wrzosek, W. (Ed.). (2004). Strategie marketingowe. Warszawa: PWE.

Yip, G. S. (1996). Strategia globalna: Światowa przewaga konkurencyjna. Warszawa: PWE.

Received on $30^{\text {th }}$ January 2013 , after revision, accepted for publication on $19^{\text {th }}$ April 2013

Piotr Markiewicz is a professor at the Department of Strategic Analysis, Cracow University of Economics, Cracow, Poland. The fields of his interests cover the methodology of strategic management expressed in the concepts, approaches and methodological instruments.

Agnieszka Żbikowska is an assistant professor at the Department of Marketing, Cracow University of Economics, Cracow, Poland. She is interested in international marketing, especially in the impact of environmental factors on the standardisation and adaptation of marketing tools, as well as in the issues related to communication and Public Relations. 


\title{
IZVORI KONKURENTSKE PREDNOSTI U OBLIKOVANJU KONKURENTSKE POZICIJE POLJSKIH IZVOZNIKA NA INOSTRANIM TRŽIŠTIMA
}

\author{
Piotr Markiewicz, Agnieszka Żbikowska \\ Fakultet za menadžment, Ekonomski univerzitet u Krakovu, Krakov, Poljska
}

\begin{abstract}
U radu su predstavljeni uloga i mesto konkurentske strategije u strateškom upravljanju preduzećem. Takođe, opisani su osnovni tipovi konkurentskih strategija, kao i izvori sticanja konkurentske prednosti, uključujući materijalne i nematerijalne resurse. U empirijskom delu rada, autori razmatraju rezultate istraživanja sprovedenih među preduzetnicima iz Poljske, koji izvoze svoje proizvode na međunarodna tržišta. Istraživanja obuhvataju uslove - pod kojima poljski izvoznici - koji oblikuju konkurentsku prednost. Rezultati istraživanja pokazuju da su glavna određenja dostizanja konkurentske prednosti koju izvoznici iz Poljske mogu ostvariti: visok kvalitet proizvoda, prilagođavanje potrebama i očekivanjima klijenata, brz i fleksibilan odziv na tržišne signale i, donekle, predstava o zemlji izvoznici.
\end{abstract}

Ključne reči: konkurentska strategija, konkurentska prednost, izvoznici iz Poljske

JEL Classification: F23 